\title{
Jean-Paul Sartre, Europeans, the "Feminine” and the Negritude Poems in the Black Orpheus
}

\author{
Nathalie Nya \\ The Pennsylvania State University, University Park, United States
}

\begin{abstract}
The paper examines the development of "Negro poetry" from the Negritude movement through the analysis of Sartre as featured in Black Orpheus (1976). Following the analysis of Sartre, the author looks at the Black/White binary and its cultural and political context, which is based on the dominance of Europeans over Blacks. Then the author examines how Blacks have attempted to subvert this binary through alternative political stands, such as the practice of anti-racism, and innovative cultural art and literary forms, such as the Negritude movement. Like Sartre, the author focuses on "Negro poetry" and examines its limits and the challenges it put forth against the White supremacist elements in White dominant culture. The author concludes that while "Negro poetry" reflects a step forward in the anti-racist development of Black political and cultural identities, it is a limiting method of approach that does not subvert enough White dominant culture. This position enables the author to argue that, for example, the essentialist, racist, and gender—and sex—biases within the representations and images of the "feminine" and Black women are not sufficiently critically re-represented in "Negro poetry" of the Negritude movement. The method of this approach is (1) to look at Sartre's writing in Black Orpheus, (2) to include the secondary literature of this text within my analysis, (3) to examine sections of "Negro poetry" as featured in Black Orpheus, and (4) to critically access the racial, sex, and gender dimensions of "Negro poetry" as they relate to the achievements of the men or artists of the Negritude movement.
\end{abstract}

Keywords: Europeans/Whites, Blacks, colonialism, race, anti-racism, gender, negritude, “feminine”

\section{Introduction}

The purpose of this paper is to examine Sartre's views of Europeans and Blacks, and the "feminine" and Black women in Negritude poetry as featured in Black Orpheus (1976). The author begins by examining the racial context from Sartre's perspective that sets the stage for the development of the Negritude movement, a cultural literary and political movement, developed by Francophone black intellectuals, writers, and politicians, such as Leopold Senghor and Aime Cesaire, in France starting in the 1930s and flourishing after World War II. Then the author examines how the use of poetry as a political and cultural literary genre enabled Black writers/poets to put into question the White supremacist and negro-phobic elements within European dominant culture. Finally, the author uses the representations and images of Black women and the "feminine" in order to show how as a critique, "Negro poetry" - an anti-racist literary art form within the Negritude movement which attempted to subvert or change the White supremacist and Negro-phobic elements within European dominant culture and within the minds and cultures of Blacks - attempted to subvert, for example, the racist depictions of

Nathalie Nya, Ph.D., lecturer, Department of Philosophy, The Pennsylvania State University. 
Black women in European dominant culture, thereby challenging an aspect of White supremacy through poetry. Following Sartre, the author concludes that while "Negro poetry" from the Negritude movement challenges White supremacy, it has its limits. Sartre is famously quoted for suggesting that the Negritude movement is just a stage within the development of Black consciousness. ${ }^{1}$ Given that Blacks, as French colonized subjects, were raised through French education, which led them to believe that they could become acculturated as French, to Sartre, the Negritude movement's attempts to subvert French European culture through the use of the French language limits the movement's effort to truly subvert French European culture because the use of the French language reflects a self-contradiction on the part of specifically Black writers/authors/poets. ${ }^{2}$

This perspective on the male dominance of White and Black men over Black women will enable the author to argue that Sartre's position on the poetry of the Negritude movement—specially the "Negro poetry" from Leopold Senghor's famous anthology, is male biased. That bias gives political and cultural advantages to the understanding of not the oppression of both Black men and women, but of Black men mostly. Furthermore, Sartre's analysis gives rise to the affirmative interpretation of the Black male poet/writer only, and thus it fails to give an account of the positive cultural and political contributions of the potential Black female author.

\section{Europeans}

\section{Europeans to Sartre After Being Seen by Blacks}

When Sartre wrote Black Orpheus in order to examine "Negro poetry" from the Negritude movement, he began by analyzing the racial context between Europeans and Blacks, which led to the development of the artistic, political, and cultural literary context of the Negritude movement. This section follows Sartre's method of approach and focuses on Sartre's understanding of the race relations between Blacks and Europeans. Thus the author begins the analysis with this context in order to set the stage for the following two sections, which focus on the content of "Negro poetry".

In Unfinished Projects, Paige Arthur says the following about Sartre's views on Europeans in Black Orpheus:

In "Black Orpheus", Sartre gave for the first time an indication that he thought that Europeans were in trouble, not because of the existential anguish that plagues everyone as a result of their freedom, but because of a kind of anguish that stems directly from the European's situation as "oppressor". ${ }^{3}$

To Arthur, Sartre in Black Orpheus establishes an analytical situation where the existence of Europeans as oppressors is to be questioned. Already in this analytical context, the subjectivity of Europeans is described in terms of their relation to the oppressed Other, the colonized and, more specifically, to Black colonized subjects. To Arthur then, Sartre makes us aware that Europeans are in trouble because their existence is defined by the oppressor and oppressed dyad, a dialectical duality that shows that the colonial system always pits the European against the person of African descent. Arthur emphasizes that for Sartre, it is the existence of the oppressed that defines the status of Europeans.

Arthur's analysis is consistent with Sartre's position in Black Orpheus. In the text, which was first published as an introduction to Leopold Senghor's Anthology of New Negro and Malagasy Poetry, ${ }^{4}$ Sartre

\footnotetext{
${ }^{1}$ See (Sartre, 1976, pp. 62-65).

2 See (Sartre, 1976, pp. 22-23).

3 See (Arthur, 2010, p. 41).

4 See (Senghor, 1969).
} 
suggests that the world has reached a point in the present where Blacks are beginning to look back at Europeans with a gaze of judgment. ${ }^{5}$ Before the author moves on with my analysis, the author wants to note that given Black Orpheus was first published as an introduction to Senghor's anthology, the content of Black Orpheus was written to support the anti-racist, political and cultural ideologies within the development of the Negritude movement. So then Black Orpheus reflects Sartre's judgment on Europeans through the eyes of Blacks. Traditionally, Sartre explains, Europeans held the power of seeing and judging Blacks without any interjection. ${ }^{6}$ Now Blacks are looking back at Europeans and, with their gaze, they question both their own human status and the proper status of Europeans. ${ }^{7}$

Sartre has a point in observing that there is a shift in the gaze between Blacks and Whites. However, as Margaret A. Majumdar claims, during the period of colonization, even with a bit of deference and although without any resolution, Blacks were able to literally look into the eyes of Whites. ${ }^{8}$ The difference now, starting after World War II, is that Blacks are looking back at Europeans in order to affirm themselves and to affirm their own human project. ${ }^{9}$ They are looking back, for example, because they want de-colonization or Independence, and they want to be treated as human beings on the same equal footing as Europeans.

In short, Blacks are reversing the gaze. The power of the gaze, or "the look", as Sartre famously references in Being and Nothingness, ${ }^{10}$ can show how a person comes to understand himself through the eyes of another. ${ }^{11}$ With "the look", Sartre explains, "I see myself because somebody sees me"12 and when that person sees me, it influences how I regard myself. In the context of Europeans caught up within the oppressor and oppressed dyad then, the look from Blacks makes Europeans see their existence as oppressors and recognize their existence with oppression.

By recognizing their existence with oppression, Europeans, through the gaze of Blacks, see the limits of their humanity and the limits of their freedom. The gaze of Blacks as David Detmer understands, creates a relation for Europeans where they are being-seen-by-the other. ${ }^{13}$ Furthermore, as Robert Bernasconi points out, Black Orpheus was primarily addressed to White people. ${ }^{14}$ It invited Whites to see themselves for the first time as Blacks saw them. ${ }^{15}$ The gaze of Blacks, then, creates a disclosure for Europeans. They are no longer safe identifying themselves as merely Europeans. Instead, they are oppressors who should identify their situations not with freedom but oppression.

While Sartre emphasizes that Black colonial subjects are looking back at Europeans, the look coming from these racialized subjects is situated within their condition of oppression (i.e., their exile from Africa, their experience with colonialism and slavery, and with the Manichean division of the world into Black and White). ${ }^{16}$ The look of Blacks then is forged within the oppressor and oppressed dyad, the colonized and colonizer dyad, the primitive and civilized dyad, and the Black and White dyad.

\footnotetext{
5 See (Sartre, 1976, p. 9).

6 See (Sartre, 1976, p. 7).

7 See (Sartre, 1976, pp. 7-8, 10-11).

8 See (Majumdar, 2007, p. 95).

9 See ( Majumdar, 2007, p. 95).

10 See (Morris, 2008, p 14).

11 See (Sartre, 1992, pp. 347-349).

12 See (Sartre, 1992, p. 349).

13 See (Detmer, 2008, p. 94).

14 See (Bernasconi, 1995, p. 207).

15 See (Bernasconi, 1995, p. 207).

16 See (Sartre, 1976, p. 19).
} 
Given the polarities between Blacks and Whites generate socio-cultural and political constraints in the lives of Blacks, it is important to examine the oppression of Blacks in order to understand why they are presently reversing the gaze on Europeans. Given the power relationships between Blacks and Whites, Blacks are oppressed, colonized and so-called racially inferior, while Whites are so-called superior based on their status as Europeans, so what human (or existential) project do Blacks have in looking back at Europeans? What is the boomerang effect of the "Black” gaze? The colonizers' attempts to restrict a Black person's freedom may produce a sense of rebellion in the Black person, which can be reflected as the boomerang effect of the "Black" gaze.

By looking back at Europeans, the colonized are then portraying an anti-conformist effort within the colonial system. The "look" then involves objectification and placement of the other body, its setting at a distance from the self, as a mutually constitutive project that is fundamentally spatial, as well as the basis for relationships of power between human beings. ${ }^{17}$ In order to address the boomerang effect of the "Black" gaze, its use and power, Sartre turns to the Negritude movement and examines the purpose and contradiction within the project of the Black poet as he consciously creates and defines Black poetry for the sake of Black people and in order to invigorate a race consciousness based on Black experiences. ${ }^{18}$ In his investigation, Sartre concludes that Black poets or Black writers testify to the "look" of this Black Other who reveals something crucial about the identity of Whites. ${ }^{19}$ As Blacks rediscover their own eyes and voices, Whites realize "the shock of being seen”, thus reversing centuries of unidirectional objectification. ${ }^{20}$ Sartre chooses to turn to the Negritude movement precisely because this political and cultural phenomenon has the main goal of subverting White racism and challenging the power relations between Blacks and Whites.

\section{The Context}

\section{"Negro Poetry" in the Literary Context of Negritude}

The author now specifies the content of Sartre's analyses on "Negro poetry". To Sartre, "Negro poetry in the French language is, in our times, the sole great revolutionary poetry" ${ }^{\text {21 }}$. To Sartre then, "Negro poetry" from the Negritude movement sets the movement apart from other cultural movements, such as Surrealism. What is revolutionary about Black poetry from the Negritude movement is that it attempts to subvert the Negro-phobic elements within French culture by giving cultural importance to writers from the French colonies. ${ }^{22}$ In other words, what is revolutionary about Negro poetry is that it presents an instance of Black anti-racism within a racist world. Moreover, as Bennetta Jules-Rosette notes, for Sartre, "as for the followers of negritude, Black poetry and the arts constitute a revolutionary force that challenges European society to address an affirmation of identity and an assertion of freedom,"23.

Thus, the poetry created through the negritude movement reflects a freeing and emancipatory project. The author would even argue in support of Bennetta Jules-Rosette's position that in his analysis of the revolutionary appearance of this poetry, Sartre places the colonized in the place of the colonizer, the Black in the place of the

\footnotetext{
${ }^{17}$ See (Boyle \& Kobayashi, 2011, p. 419).

18 See (Sartre, 1976, p. 11).

19 See (Charmé, 1991, p. 210).

${ }^{20}$ See (Charmé, 1991, p. 210).

21 See (Sartre, 1976, p. 11).

22 See (Watts, 2008, p. 195).

23 See (Jules-Rosette, 2007, p. 268).
} 
White, in order to better convince his readers of the ways the Black poet has reserved the dialectic and challenged White supremacy. ${ }^{24}$ In other words, by turning the attention to Blacks, Sartre is able to show what these Blacks have to offer to society and how these Blacks are able to put into question White privilege. In Sartre's analysis, Blacks are challenging the beliefs that Whites are superior to any other race and therefore they should politically, economically and racially dominate members of other races in society. Furthermore, as V. Y. Mudimba observes in The Invention of Africa, Sartre presents a means of struggle against the European ideology and affirms the right of people of African descent to fashion a new mode of thought, of speech, and of life. $^{25}$ In Black Orpheus then, Sartre reflects on the creativity of the Black Diaspora. ${ }^{26}$

Before the author turns to the content of Sartre's analysis of Black poetry, the author wants to note that with the few exceptions of female writers, such as Suzanne Cesaire and Paulette Nardal, ${ }^{27}$ the Black poets and writers of the Negritude movement were mostly male. Among these male poets and writers, the most famous ones include Leopold Senghor and Aime Cesaire. Both of these writers are included in Sartre's discussion in Black Orpheus $^{28}$ and the content of their writings influences Sartre's definition of the Black poet and of "Negro poetry". Therefore, the Black poet for Sartre is inherently male. In my analysis of Sartre's views on the Black poet then, the author refers to the Black poet as "the Black male poet".

The Black male poet from the French colonies, who has been taught French in school, ${ }^{29}$ uses the European language in order to communicate with and unite the colonized living within the limits of French colonization, since these Blacks do not have any other common language besides French. ${ }^{30}$ Yet since the goal of the Black male poet is to forgo the Negro-phobic elements within French culture, the use of the French language limits his project. In other words, "when the Negro declares in French that he rejects French culture, he takes in one hand that which he has pushed aside with the other" ${ }^{\text {"31 }}$. The project of the Black male poet then is built within cultural and linguistic tensions. The achievement of his project represents a cultural and epistemological impossibility.

Ultimately, the Black male poet cannot reject French. The French language is part of who he is. What the Black male poet does with the French language then is to reserve its value in order to use the language to his advantage. ${ }^{32}$ The Black male poet then, appropriates the French language and this, in part, is the power of Black poetry. ${ }^{33}$ Thomas W. Busch observes that:

[the] French colonizer has set itself up in the minds of the colonized through teaching them the French language. [...] The French language, Sartre points out, reflects a historical collectivity. It has been forged over time to respond to specific, contingent needs and circumstances, and is unsuitable to furnish the Negro "with the means of speaking about himself, his own anxieties, his own hopes". For the Negro to speak prose, a straightforward use of words, would be to fail to speak the Negro's experience. Poetry allows for a speaking of experience that simultaneously performs an "auto-destruction of language". ${ }^{34}$

\footnotetext{
${ }^{24}$ See (Gyssels, 2005, p. 636).

25 See (Mudimbe, 1988, p. 84).

${ }^{26}$ See (Liauzu, Benallegue, \& Hamzaoui, 1984, p. 3).

27 See (Sharpley-Whiting, 2002, pp. 16-20, 68-79, 80-102).

28 See (Sartre, 1976, pp. 33, 56).

${ }^{29}$ See (Sartre, 1976, p. 24).

30 See (Sartre, 1976, p. 22).

31 See (Sartre, 1976, p. 23).

32 See (Irele \& Sartre, 1975, p. 40).

33 See (Yillah, 2005, p. 64).

34 See (Busch, 1999, p. 69).
} 
For the reason that Blacks cannot use straightforward French in order to combat the Negro-phobic elements within French culture, the Black male poet turns to poetry in order to achieve this goal.

Comparing, as Sartre does, the use of language within the project of the Black male poet to the use of language by the White proletariat for his fight against class struggle might explain why the White proletariat, although oppressed by Bourgeois reason, capital and culture, ${ }^{35}$ "rarely uses the language of poetry" ${ }^{36}$ This comparison might also explain the differences between class and racial oppression. Based on Sartre's analysis, the author concludes that class oppression is based on a rational endeavor, while racial oppression is not. ${ }^{37}$ So, in order to combat the irrational component of Negro-phobia (of racism), the Black male poet has to become creative, devious and sneaky with language, while the White proletariat has to become a technician of language in order to grasp and combat the rationalism, the materialism and the positivism of class oppression. ${ }^{38}$

Precisely because racism embodies numerous or countless "human" contradictions and irrational taboos, the Black male poet has to forge asymmetrical—almost beyond the realm of logic, and creative paths of approach to the problem of racism. It is vital to examine the Black male poet's poetry in order to understand the creativity and subversiveness of his poems. In Black Orpheus Sartre does just this. Specifically Sartre examines the poems in Senghor's Anthology of New Negro and Malagasy Poetry, the anthology with which Black Orpheus was originally published. In Black Orpheus, Sartre quotes poems by mostly Black male writers about 28 times. Some of these poems are quoted with the names of the writers while most of them are not. To name a few themes, these quoted poems are about race, Africa, the colonies, Europe, reason, passion, nature, men, women and sex. ${ }^{39}$

For the sake of my inquiry, the author focuses for the most part on poems that feature the situations of Black women and that include the sexual dimension of the Black experience between Black men and women. The analysis moves into this specific topic because the poems from Senghor's anthology are very complex and various in nature. So rather than presenting in this paper the various ways these poems attempt to subvert White supremacy, the author focuses on one aspect: the poetic forms which focus on the intersection between gender, sex and race within the situation of Black women. In other words, the author focuses on how these Black male poets, in the anthology as referenced by Sartre, attempt to change both the racist and sexist images and representation of Black women in White dominant culture and, in the minds and culture of Blacks.

\section{Gender, Sex, Race and the Critical Particulars of "Negro Poetry"}

\section{The Representation of the "Feminine" and Black Women in "Negro Poetry"}

In Black Orpheus, there are six poems cited that include the perceived situation of women and the objectifying assumptions about the "feminine". ${ }^{40}$ By the "feminine" and in relation to "Negro poetry" as featured in Senghor's anthology and as referenced by Sartre in Black Orpheus, the author means to say any ideas-material or immaterial and real or imagined, coming from either male or female (but mostly male given the context of this analysis), associated with the description of a person identified as/assumed to be, a potential gender or sexed female subject. In these six poems on the perceived situation of women and the objectifying

\footnotetext{
35 See (Haddour, 2005, pp. 289-290).

${ }^{36}$ See (Sartre,1976, pp. 11-12).

${ }^{37}$ See (Sartre,1976, pp. 11-2).

38 See (Sartre,1976, pp. 11-12).

39 See (Sartre,1976, pp. 8, 9, \& 26).

40 See (Sartre, 1976, pp. 8, 20, 28, 45, \& 48).
} 
assumptions about the "feminine", the nude body of Black women, their dress code, their moods, their self-representation as Black dolls, their smile, their sex organs, their Blackness, their condition as women, mothers and lovers are described. ${ }^{41}$ These poems, written by Black men, treat women not as subjects but as objects of their inquiry and as objects of their sexual desire. These Black men, along with Sartre, since he chooses to quote these poems, treat Black women as the object of the gaze and as the object of their sexual desire. Sartre's and these Black men's claims on Black women then are exceptional because they attempt to positively define Black women against the primitivism associated with these women in the minds and culture of White Supremacy culture. ${ }^{42}$

As Bell Hooks claims in Black Looks, "to love Blackness is dangerous in a White supremacist culture”. ${ }^{3}$ Given that the mind and body of Blacks have been described in White culture as a source of inferiority, the abject, the inhumane and the primitive, as T. Denean Sharpley-Whiting shows in Black Venus, ${ }^{44}$ to claim the love and desire for Black female bodies is to undermine the White hatred and Black self-hatred attributed to Blackness. It is also to put in danger the remains of White Supremacy in White culture. The professed love and admiration for the Black female can be seen as a site of resistance to White Supremacy. By claiming and writing about the desire for Black women, these Black poets subvert White supremacy.

Capturing the famous slogan from the 1960s Black Power Movement, "Black is beautiful", ${ }^{5}$ Sartre (quoting these poems) and these Black male poets of the Negritude movement are affirming what is unapologetically beautiful about Black women. These women are beautiful to these men because these women are mothers, lovers, representations of dolls and also beautiful. On the part of Sartre, it shows that he recognizes the beauty of Black women and on the part of these Black poets, it shows illustrations of self-love and the love of Black women.

Before I move ahead, I want to note that, especially on the part of Sartre, as Stuart Zane Charme notes, the beauty that Sartre finds in these Black poets' description of Black women's bodies does not reflect the position that he has on the bodies of women in general. ${ }^{46}$ For the most part, as it has been shown in his description of the feminine in Nausea for example, where the male protagonist, Antoine Roquentin, is nauseated by the female body of a White woman, ${ }^{47}$ Sartre tends to describe the body of women in the negative and with much ambivalence. $^{48}$

Despite the great admiration, I have for both Sartre and these Black male poets, I still think that the

\footnotetext{
${ }^{41}$ See (Sartre, pp. 8, 20, 28, 45, 48, \& 51).

42 I want to note that in treating Black women as the object of the gaze, these Black male poets and Sartre run a fine line between the positive objectification - the positive admiration of Black women and the hyper-sexualization of these women. However, since the writings of these poets are in awe with the beauty of women, I give some credit to these men for "admiring" the beauty of women - or for gazing upon the body of Black women. I conclude that even in my criticism of these men, these men are not necessarily hyper-sexualizing Black women. These men are treating Black women as the object of sexual desire and rather not as sex objects. From this perspective then, and if I were to become critical, I would say that rendering Black women in poetry as "the object of sexual desire" transcend the race problems the Negritude movement wants to tackle; i.e., the racial objectification of women as being non-human. However, rendering Black women in poetry as "the object of sexual desire" may not transcend the gender and sexual issues within the situation of these women. Thus these poems, at least to me are exceptional because they attempt to transcend European racism directed at the representation of Black women.

43 See (Hooks, 1992, p. 9).

44 See (Sharpley-Whiting, 1999, pp. 16-31).

45 See (Goering, 1972, p. 231), (Lang, 2004, pp. 730, 739), and (Simmons, 1978, p. 54).

46 See (Charmé, 1991, p. 148).

47 See (Sartre, 2013, p. 59).

48 See (Charmé, 1991, pp. 147-149).
} 
manner in which the beauty and experience of Black women is expressed by these poets needs to be problematized. To begin, in the Anthology, a full perspective on the experience and beauty of Black women would have included the participation of Black women as poets and writers. From this Anthology, given that, based on the colonial context, the anthology was put together as "a talent show" or as "a testimony" of these Black writers' literary skills, sensibility and humanity, we do not know how the Black female author is revered and "celebrated".

Senghor could have, for example, invited Suzanne Cesaire and Paulette Nardal to participate in the Anthology. Since these poems on Black women are not also written by Black women, we are not given a full perspective on the experience and beauty of Black women. From these poems, we gather the experience and Blackness of these women in terms of female gender stereotypical archetypes. In the poems, Black women are archetypically described as mothers, lovers, and dolls and as objects of sexual desire. However, there is nothing in these poems about the roles that these women play in society apart from their relations to Black men. For example, at the beginning of Black Orpheus, Sartre quotes a passage from one of the poets in the Anthology:

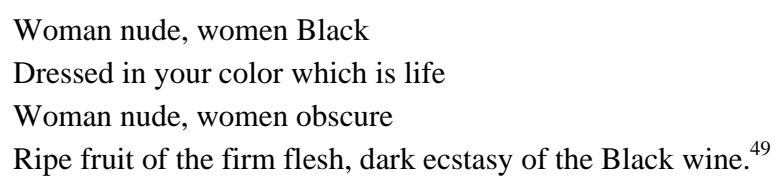

We only learn from this poem how the woman is subjected to the male gaze. We know she is both literally and figuratively naked and that her body is associated with life, color, nature and objects. But who is this nude woman? How does she perceive herself? If a Black woman were to write about the nudity of a Black woman, would she come up with the same conclusion as the author of this poem? Perhaps rather than comparing the body of Black women with nature, a Black female poet would compare the body of Black women with life in the city and she would also compare the body of Black women among each other: by size, shape and shades of skin color. The Black female poet would describe the body of Black women in these ways while at the same attempting to avoid body image issues and the infamous problem of racial colorism among both Black and White people.

Rather than reflecting on the body of Black women in terms of darkness (i.e., "the dark ecstacy of the Black wine”), as the Black male poet does, which in turn reflects the traditional binary opposition between Black and White people, between darkness and lightness/whiteness, influenced by the racial ideologies found in White dominant culture, the Black female poet can challenge the binary of racial colorism by describing Black female bodies in terms of shades of brown and yellow, and even in terms of shades of purple (i.e., the purple lips of some Black women). Given my interest to find unique ways to imagine and represent the body of Black women, the author finds that the poem referenced above, despite its beauty, is still influenced by the type of racial binary, between Blacks and Whites, primarily originating from White dominant culture. From this poem then, we can see how despite his great effort, the Black male poet or the author of this poem in particular, at least when it comes to issues on the intersection between race and gender differences, remains influenced by ideologies of White dominant culture-an influence that does not only show the limits of using the rhetoric of the French language in order to work against the "racist" roots of the language, but also shows the incredible impression of "racist" European ideologies over the minds and thoughts of Blacks. Perhaps if the Black male

49 See (Sartre, 1976, p. 8). 
poets could think of themselves as people who can transcend the racial laws of the Black and White binary, maybe they would have the possibility to discover themselves the beyond realms of White cultural rules.

What the author says here also affects the Black female poet, because, although not acknowledged by Sartre, she is a byproduct of the French language and the dominant European French culture. The difference then between the Black male poet and the Black female poet, given the context of Senghor's anthology and Sartre's Black Orpheus, the Black female poet would be granted the attempt to at least try to define herself, in her own voice with the great and beautiful possibility of either failing or succeeding to poetically write about herself, other Black women and even other people in general.

Furthermore, Sartre notes that some of these poems, like Aime Cesaire's poems and the one the author has referenced above, reflect "a perpetual coupling of women and men metamorphosed into men" ${ }^{50}$ Some of these poems then, even while they may be on women, represent the erasure of women from Negritude. These poems do not represent dialogical relations between Black men and women. There is no evidence in these quoted poems that these male poets speak to Black women. What these poems represent is the ways Black women are objectified and are even subjected to a tint of exoticism (since these men compare the body of Black women with nature). The fact that Sartre does not take issue with the lack of the female perspective in the Negritude movement, and more specifically in the Anthology, shows that the shift that occurs through the reversal of the gaze between Blacks and Whites is based on the relation between European men and men of African descent.

The Black female, she cannot gaze back because she does not possess as a woman the power to objectify like a man, ${ }^{51}$ becomes voiceless. Since she is only seen as being the subject of the male gaze, the Black female is "robbed of her possibilities" 52 as an author, as an agent. By being robbed of her possibilities as an agent, the Black female is identified as being incapable of reserving the gaze between Blacks and Whites. Sartre and these Black male poets do not see her as being capable of looking back at Europeans with the request of becoming humanized and decolonized. The Black female then cannot objectify European men or even European women. The Black female, according to her lack of agency in Sartre's and these Black male poets' writings, is at the bottom of the "human" barrel. Her situation within the dialectic of colonialism is that of subjective powerlessness.

The analysis on how Black women are not seen by Sartre and Black male poets as capable of being agents shows that these women are subordinate to men in general. In the analysis, the author shows how men observe Black woman, but the reverse doesn't happen. Precisely because of this situation, there is a power relationship between Black women and men that prevents these women from objectifying men. Lacking the power, then as subjects to objectify others, Black women become subordinate to men in general.

As Hazel E. Barnes observes, "there can be no doubt that a full investigation of the linguistic codes in Sartre's writing would reveal him to be a man comfortably ensconced in a world of male dominance". ${ }^{3}$ In "How Sexist Is Sartre?” Bonnie Burstow also comes to the conclusion that Sartre's writing is based on male dominance, and she argues that sexism may be found in Sartre's writing. ${ }^{54}$ In an interview with Simone de Beauvoir, Sartre admits that there are some "macho" undertones in his writing. ${ }^{55}$ De Beauvoir observes that

\footnotetext{
50 See (Sartre, 1976, p. 48).

51 See (Duran, 2004, p. 273).

52 See (Murphy, 1987, p. 114).

53 See (Barnes, 1990, p. 341).

54 See (Burstow, 1992, p. 32).

55 See (Sartre, 1977, p. 95).
} 
Sartre neglects the oppression of women throughout his writing career, and she insists that one may find traces of "machismo" in his works. ${ }^{56}$ Sartre feels that she may be exaggerating a little but he seems to concede the point. ${ }^{57}$

These references suggest that Sartre's choice to include poetry on the nudity of Black women in Black Orpheus reflects his attempts to allow his readers to gaze further upon the body of Black women, as it has been historically done, for example with the nude images of African women in National Geographic. ${ }^{58}$ As it has been shown with the study of, for example, Venus the Hottentot—Sarah Baartman, the South-African woman sold into slavery during the 19th century, Europeans used to put nude Black women on display for their exotic features-dark skin and large buttocks. Through the visual display of Black women within the European socio-cultural context, Black women were hyper-sexualized. They were seen as exuding excessive sexual prowess, which, in turn, left them subject to an unusual form of sexism. These Black women could be touched, photographed and even raped by Europeans. So when Sartre in Black Orpheus references poems that describe the nudity of Black women, he is in part participating in the socio-cultural European tradition which took an "objectifying" interest in the nudity of Black female bodies. Thus it is possible to admire the beauty of Black women while remaining sexist.

All things considered, the perspective of women is not integrated into the greater whole of Sartre's analysis on colonial context of the Negritude movement. Sartre's Black Orpheus omits the effects and experience of women in the Negritude movement. A close examination on the experience of Black women would have allowed Sartre to discover how, as Oyeronke Oyewumi notes, colonized women suffered from a "double colonization", one from Europeanization and the other from indigenous tradition imposed by men of African descent. ${ }^{59}$ Black women then were socially placed into a double bind—one of gender and the other of race, which does not even Black men could experience.

The intersection among racial, cultural and gender oppression which characterizes the situation of colonized women is lost in Sartre's analysis. Thus Sartre's admission that the Negritude movement inverts the colonists' ruse and espouses an anti-racist racism falls into just dangerous binary oppositions aligning as thesis/antithesis: White/Black, Bourgeois/Proletariat, and European/African. ${ }^{60}$ The White/Black, Bourgeois/Proletariat, and European/African binaries, according to me, are overarched by the dialectic between the European man and the man of African descent. This dialectic is highly problematic and rather not gender neutral. By looking at the socio-political pairs of concepts that are constructed as opposite to each other, Sartre fails to acknowledge how these concepts are intersecting with one other. So, for example, if we were to look at the binary between European and Africans, we might fail to acknowledge how certain members of these individual groups — such as the men within each group — enjoy patriarchal rights over their female counterparts. Through this example then, which emphasizes patriarchal privileges instead of racial privileges, European men and African men have more in common than African men and African women. Thus Sartre, like the Black male poets, fails to give an intersectional account of how race and gender oppression intersect within the situation of Black women, and thereby places Black women in an even further situation of oppression that is not apparent

\footnotetext{
${ }^{56}$ See (LaCapra, 1982, p. 27).

57 See (LaCapra, 1982, p. 27).

58 See (Eck, 2003, p. 705).

59 See (Oyewumi, 2006, p. 256).

60 See (Barber, 2001, p. 92).
} 
in the situation of European and African men.

\section{Conclusion}

In this paper, I have presented three specific points in terms of Sartre's analysis of "Negro poetry" of the Negritude movement as featured in Black Orpheus. I first began by setting the stage for Sartre's analysis that shows how the racial context between the relation of Europeans/Whites and Blacks influenced the literary and artistic developments of the Negritude movement. Through Sartre's analysis of this cultural and political phenomenon, we see how Black male writers/authors/artists, by directing in part the Negritude movement towards Europeans and not just at Blacks, were able to put into question the power relationship between Whites and Blacks. Then specifically, I examined the literary and racial context of "Negro poetry" as Sartre referenced in Black Orpheus in order to show the political and cultural ingenuity of this literary and artistic form. Finally, in order to show the political and cultural changes that "Negro poetry" brought about-a movement, which gave the opportunity to Blacks to publically speak up against and in front of Europeans, the author focuses on how this poetic genre contributed to the changes in the image and representation of Black women. However, the analysis is quick to remark that despite the great efforts of the Black "male" poet, the representation and images of Black women in relation to how they intersect with these women's racial, sex, and gender situations, need to be further developed and problematized by not only including the perspectives of Black female authors but of also including representation and images that challenge the patriarchal dominance of both White and Black men over Black women.

Despite the fact that I am critical of the segments of "Negro poetry" that she has presented in this paper, the author sees like Sartre, a cultural and political use value to the anti-racist developments of "Negro poetry" within the Negritude movement. At last, it enabled the Black "male” poet to speak up "without fear", but with individual risks, social and political repercussions, and with a sense self-agency, against the White supremacist elements of White European dominant culture. And while I do not want to leave aside my feminist concerns against the Black "male” poet as described and analyzed by Sartre, I acknowledges, but with some failures, the Black "male" poet's attempts to re-represent and re-imagine the situation of Black women free of not only racism but of also sexism.

\section{References}

Arthur, P. (2010). Unfinished projects: Decolonization and the philosophy of Jean-Paul Sartre. London: Verso.

Barber, M. D. (2001). Sartre, phenomenology and the subjective approach to race and ethnicity in Black Orpheus. Philosophy and Social Criticism, 27(3), 91-103.

Barnes, H. E. (1990). Sartre and sexism. Philosophy and Literature, 14(2), 340-347.

Bernasconi, R. (1995). Sartre’s gaze returned. Graduate Faculty Philosophy, 18(2), 201-221.

Boyle, M., \& Kobayashi, A. (2011). Metropolitan anxieties: A critical appraisal of Sartre's theory of colonialism. Transactions of the Institute of British Geographers, 36(3), 408-424.

Burstow, B. (1992). How sexist is Sartre?. Philosophy and Literature, 16(1), 32-48.

Busch, T. W. (1999). Circulating being: From embodiment to incorporation: Essays on late existentialism (1st ed). New York: Fordham University Press.

Charmé, S. L. (1991). Vulgarity and authenticity: Dimensions of Otherness in the world of Jean-Paul Sartre. Amherst: University of Massachusetts Press.

Detmer, D. (2008). Sartre explained: From bad faith to authenticity. Chicago, Ill.: Open Court.

Duran, J. (2004). Sartre, gender theory and the possibility of transcendence. Philosophy and Social Criticism, 30(3), 265-281.

Eck, B. A. (2003). Men are much harder: gendered viewing of nude images. Gender and Society, 17(5), 691-710. 
Goering, J. M. (1972). Changing perceptions and evaluations of physical characteristics among Blacks: 1950-1970. Phylon, 33(3), 231-241.

Gyssels, K. (2005). Sartre postcolonial? Relire Orphée Noir plus d’un demi-siècle après (Post-colonial Sartre? Re-reading Black Orpheus more than 50 years later). Cahiers d'Études Africaines, 45(179/180), 631-650.

Haddour, A. (2005). Sartre and fanon: On negritude and political participation. Sartre Studies International, 11(1/2), $286-301$.

Hooks, B. (1992). Black looks: Race and representation. Boston, MA: South End Press.

Irele, A., \& Sartre, J. P. (1975). A defence of negritude: A propos of Black Orpheus by Jean Paul Sartre. Transition, 50, 39-41.

Jules-Rosette, B. (2007). Jean-Paul Sartre and the philosophy of négritude: Race, self, and society. Theory and Society, 36(3), 265-285.

LaCapra, D. (1982). Sartre and the question of biography. The French Review. Special Issue, 7, 22-56.

Lang, C. (2004). Between civil rights and black power in the Gateway city: The Action Committee to improve opportunities for Negroes (Action), 1964-1975. Journal of Social History, 37(3), 725-54.

Liauzu, C., Benallegue, N., \& Hamzaoui, S. (1984). Les Intellectuals Francais Au Mirroir Algerien (French intellectuals in the image of Algerians). Nice: Universite de Nice.

Majumdar, M. A. (2007).Postcoloniality: The French dimension. New York: Berghahn Books.

Morris, K. J. (2008). Sartre. Malden, MA: Blackwell.

Mudimbe, V. Y. (1988). The invention of Africa: Gnosis, philosophy, and the order of knowledge. Bloomington: Indiana University Press.

Murphy, J. S. (1987). The look in sartre and rich. Hypatia, 2(2), 113-24.

Oyewumi, O. (2006). Colonizing bodies and minds. In The Post-Colonial Studies Reader (2nd ed.). New York: Routledge.

Sartre, J.-P. (1976). Black orpheus. Paris: Présence africaine,

Sartre, J.-P. (1977). Life situations: Essays written and spoken (1st ed.). New York: Pantheon Books,.

Sartre, J.-P. (1992). Being and nothingness: A phenomenological essay on ontology. New York: Washington Square Press .

Sartre, J.-P. (2013). Nausea. New York: A New Directions Paperbook,.

Senghor, L. S. (1969). Anthologie de La Nouvelle Poésie Nègre et Malgache de Langue Française (Anthology on new Negro and malagasy poetry in the French language) (2nd. ed.). Paris: Presses universitaires de France.

Sharpley-Whiting, T. D. (1999). Black venus: Sexualized savages, primal fears, and primitive narratives in French. Durham, NC: Duke University Press.

Sharpley-Whiting, T. D. (2002). Negritude women. Minneapolis: University of Minnesota Press.

Simmons, R. G. (1978). Blacks and high self-esteem: A puzzle. Social Psychology, 41(1), 54-57.

Watts, R. H. (2008). Difference/Indifferenc. In Race after sartre. New York: SUNY Press.

Yillah, D. (2005). Sartre and Black African: Cross-cultural issues. International Journal of Francophone Studies, 8(1), 53-70. 